\title{
A new species of Hammerschmidtiella Chitwood, 1932 (Nematoda, Thelastomatidae) parasite of the brown cockroach Periplaneta brunnea Burmeister, 1838 (Blattodea, Blattidae) from Argentina
}

\author{
Nora Beatriz Camino ${ }^{1,2}$ and Cristina de Villalobos ${ }^{1,3^{*}}$ \\ ${ }^{1}$ Investigador CIC Comisión de Investigaciones Científicas de la Provincia de Buenos Aires 526 e/10 y 11, La Plata; \\ ${ }^{2}$ Centro de Estudios Parasitológicos y de Vectores Calle $2 \mathrm{n}^{\circ}$ 584, 1900 La Plata; ${ }^{3}$ Facultad de Ciencias Naturales y Museo,
}

UNLP, Argentina

\begin{abstract}
A new species of the genus Hammerschmidtiella, H. eltalaensis sp. nov. parasitizing a brown cockroach Periplaneta brunnea Burmeister from El Tala river, Catamarca, Argentina, is described and illustrated. It is characterized by having the cuticle striated, without lateral alae, mouth with three toothed lips and eight labial papillae, amphids small and pore shaped, buccal capsule short, wide, with four mobile teeth, oesophagus with metacorpus valvate, isthmus cylindrical and thin surrounded by nerve ring, and a rounded basal bulb heavily muscled and valvate, the vulva is slightly protruding and lies in the anterior third of the body, didelphic, prodelphic, eggs small and elongate, the male with one spicule, without gubernaculum, the genital papillae arranged in one pair of small preanal papillae, and two postanal papillae, one pair is the base of the tail appendage. Tail appendage very long, thin, and reaching almost one third of the length of the body in the female. In the male the posterior end of the body abruptly truncated posterior to anus with spine-like long tail appendage.
\end{abstract}

\section{Keywords}

Nematoda, Hammerschmidtiella eltalaensis, new species, cockroach

\section{Introduction}

The genus Hammerschmidtiella has been proposed by Chitwood (1932) to locate Oxyuris diesingi Hammerschmidt, 1838, and $O$. blattae-orientalis Hammerschmidt, 1847. Chitwood (1932) redescribed these species and put both of them in the synonym Hammerschmidtiella diesingi (also see Serrano Sanchez 1945; Rao 1958; Biswas and Chakravarty 1963; Rao and Rao 1965; Farooqui 1966; Kloss 1966; Gupta and Kaur 1978; Spiridonov 1984; Adamson and Nasher 1987; Zervos 1987; Singh and Kaur 1988; Shah 2007).

Adamson and van Waerebeke (1992) made a revision of the family Thelastomatidae and listed eleven species of Hammerschmidtiella parasites of Diplopoda and Blattodea from Europe, India, Asia, New Zealand, and North and South America. In their review these authors comment that $H$. poinari Gupta et Kaur, 1978 may be a synonym of $H$. diesingi and considered H. aspiculus Biswas et Chakravarty, 1963 as valid species, although Farooqui (1966) considered this species a synonym of $H$. diesingi.

Recently Jex et al. (2005) described another new species, $H$. hochi in cockroaches from Australia and compared it with the species of the genus Hammerschmidtiella, although Singh and Agarwal (1998) considered H. singhi Rao et Rao, 1965 a synonym of $H$. diesingi. The fact that species of the genus Hammerschmidtiella had been collected from cockroaches (Jex et al. 2005) is important because cockroaches can carry human pathogens, such as Salmonella and E. coli, which can result in human diseases, such as food poisoning or diarrhea. They also can transmit the hepatitis virus and have been known to spread dysentery and typhoid fever (Brenner et al. 1987, Vythilingam et al. 1997). Products of cockroach infestations, including saliva, feces and cast skins, are sources of allergens and develop allergies that can trigger asthma in people, especially children (Eggleston et al. 1999; Sporik et al. 1999; Baumholtz et al. 2008). For all these reasons the cockroaches 
must be controlled, eliminating the use of insecticides that cause resistance in insects, and replacing them with natural parasites and pathogens.

In this investigation we described a new species called H. eltalaensis that belongs to the genus Hammerschmidtiella, parasitizing a brown cockroach Periplaneta brunnea from Argentina.

\section{Materials and methods}

Twenty nymphs of the cockroach Periplaneta brunnea Burmeister, 1838 (Blattodea, Blattidae) were found in the river

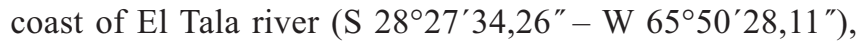
Catamarca province, Argentina. They were collected by hand during 2010 autumn and were put in individual paper containers. The insects were dissected in Petri dishes filled with distilled water under a stereoscope microscope. A transverse incision was made along the posterior end of the abdomen and the digestive tract was removed to obtain the parasites. The nematodes $(\mathrm{n}=57)$ were killed by placing them in distilled water at $60^{\circ} \mathrm{C}$ for $2 \mathrm{~min}$. They were removed to $50 \%$ TAF solution in water for 48 hours then into pure TAF. Forty seven specimens were used for drawings, photographed and measured with the aid of a lucida camera mounted on a Zeiss compound microscope. Measurements were made using an ocular micrometer and are given as the mean \pm standard deviation followed by the range in parentheses. All measurements are given in micrometres.

In order to develop a more complete description of characters, we carry out an ultrastructural analysis using a scanning electron microscope (SEM), which has proven to provide a better assessment of cuticular detail and to clarify the status of the nematodes. The ten remaining specimens were fixed in a cold solution of $1.5 \%$ glutaraldehyde $/ 1.5 \%$ formaldehyde in $0.1 \mathrm{M}$ acidulate buffer ( $\mathrm{pH} 7.35$ ) overnight, postfixed in cold aqueous solution of $1 \%$ osmium peroxide overnight. The nematodes were dehydrated in an increasing ethanol series, critically point-dried, mounted on bronze blocks and gold-sputter coated and observed and photographed using a JEOL JSM $6360 \mathrm{LV}$.

Holotype and allotype specimens are deposited in the Invertebrate Department, Museo de Ciencias Naturales, La Plata, Argentina (MLP). Paratypes are deposited in the Centro de Estudios Parasitológicos y Vectores (CEPAVE), Nematoda collection (NC), La Plata, Argentina.

\section{Results}

Hammerschmidtiella eltalaensis sp. nov.

Type material: Holotype and allotype (MLP). Paratypes. Type locality: El Tala river (S 28 $27^{\prime} 34^{\prime \prime}-\mathrm{W} 65^{\circ} 50^{\prime} 28^{\prime \prime}$ ), Catamarca province, Argentina.

Host: Nymphs of the cockroach Periplaneta brunnea (L.) (Blattodea, Blattidae).

Etymology: The name refers to the location where the host and the nematode were found.

Site of infection: Intestine, midgut.

Prevalence: $60 \%$.

Number of nematodes per nymph: 1-12.

\section{Description}

Female (Table II) has the cephalic extremity rounded (Figs 1, $9,10)$. Cuticle striated with rings along the entire body (Figs. $1,9,10)$. Mouth surrounded by three toothed lips and eight labial papillae (Figs 7, 8). Amphids small and pore shaped (Figs 3, 8). Buccal capsule short, wide with two mobile teeth on each side of mesostom (Figs 3,7). Oesophagus short and

Table I. Reports of cockroaches as hosts of Hammerschmidtiella species

\begin{tabular}{lll}
\hline Cockroaches species & $\begin{array}{c}\text { Hammerschmidtiella } \\
\text { species }\end{array}$ & \multicolumn{1}{c}{ References } \\
\hline Blatta orientalis & H. diesingi & $\begin{array}{l}\text { see revisión Adamson M.L. } \\
\text { and van Waerebeke D. (1992) }\end{array}$ \\
Blatta orientalis & H. neyrai & Serrano Sánchez A. (1945) \\
Ceratoblatta unulivitta & H. mackenziei & Zervos S. (1987) \\
Corydia sp. & H. singhi & Rao P.N. and Rao V.J. (1965) \\
Eubladerus sp. & H. acreana & Kloss G.R. (1966) \\
Hormetica scrobiculata & H. diesingi & Kloss G.R. (1966) \\
Leucophaea maderae & H. diesingi & Pessoa S.B. and Correa C. (1926) \\
Panesthia cribrata & H. hochi & Jex A.R. et al. (2005) \\
Periplaneta americana & H. diesingi & see revision Adamson M.L. \\
& & and van Waerebeke D. (1992) \\
Periplaneta americana & H. basiri & Singh H.S. and Kaur H. (1988) \\
Periplaneta americana & H. hochi & Shah (2007) \\
Periplaneta australasiae & H. diesingi & Jarry D.T. (1964) \\
Petasodes mouffeti & H. diesingi & Kloss G.R. (1966) \\
Periplaneta brunnea & H. eltalaensis sp. nov. & this report
\end{tabular}




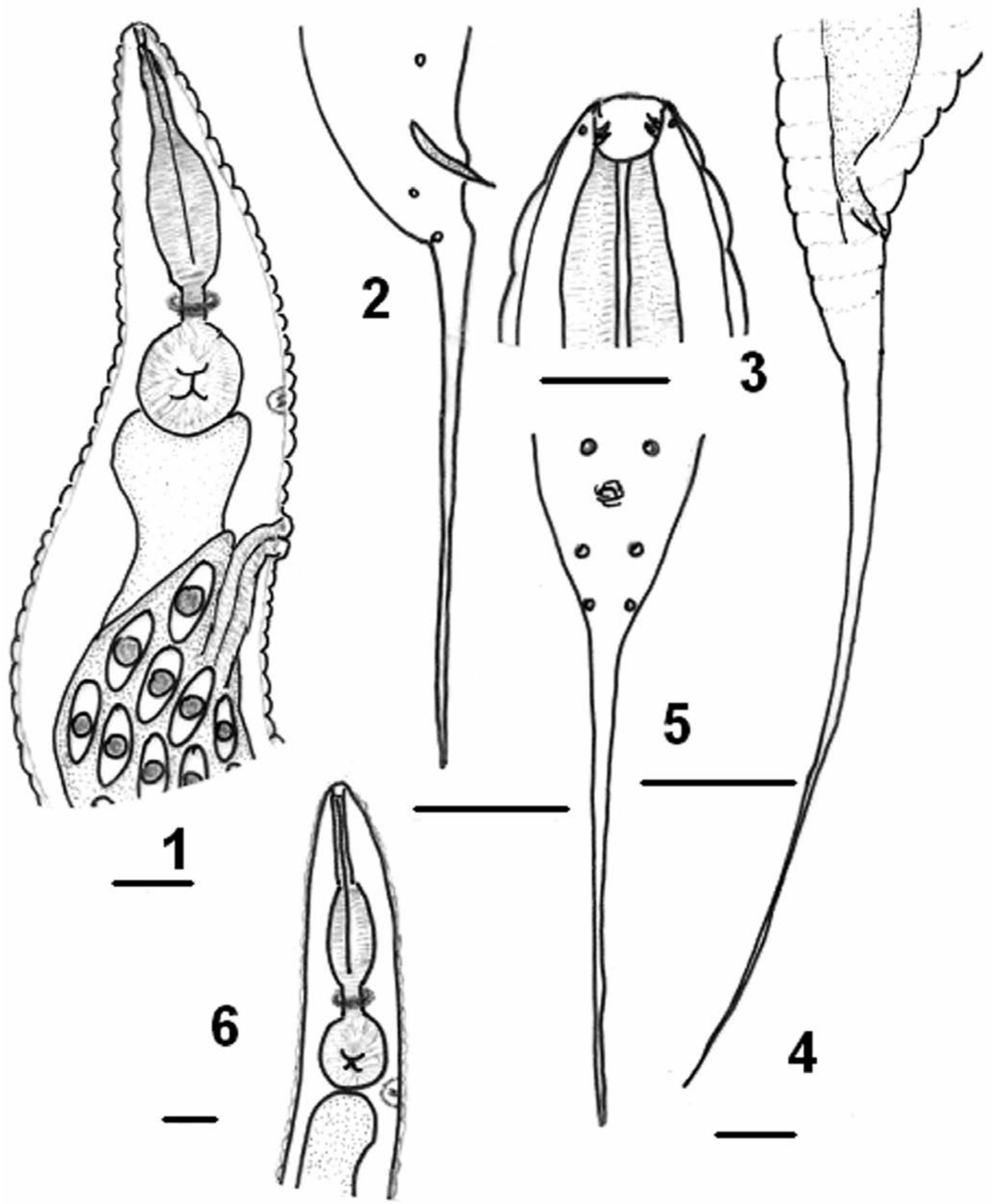

Figs 1-6. Hammerschmidtiella eltalaensis sp. nov. 1. Anterior end of female, oesophagus, vagina and eggs. 2. Posterior end of male in lateral view. 3. Buccal capsule of female. 4. Posterior end of female. 5. Posterior end of male in ventral view. 6. Anterior end of male. Scale bars $1,4=100 \mu \mathrm{m} ; 2,3,5,6=50 \mu \mathrm{m}$ 
Table II. Morphometric data for Hammerschmidtiella eltalaensis sp. nov., measurements in $\mu \mathrm{m} \pm$ S.D. (range)

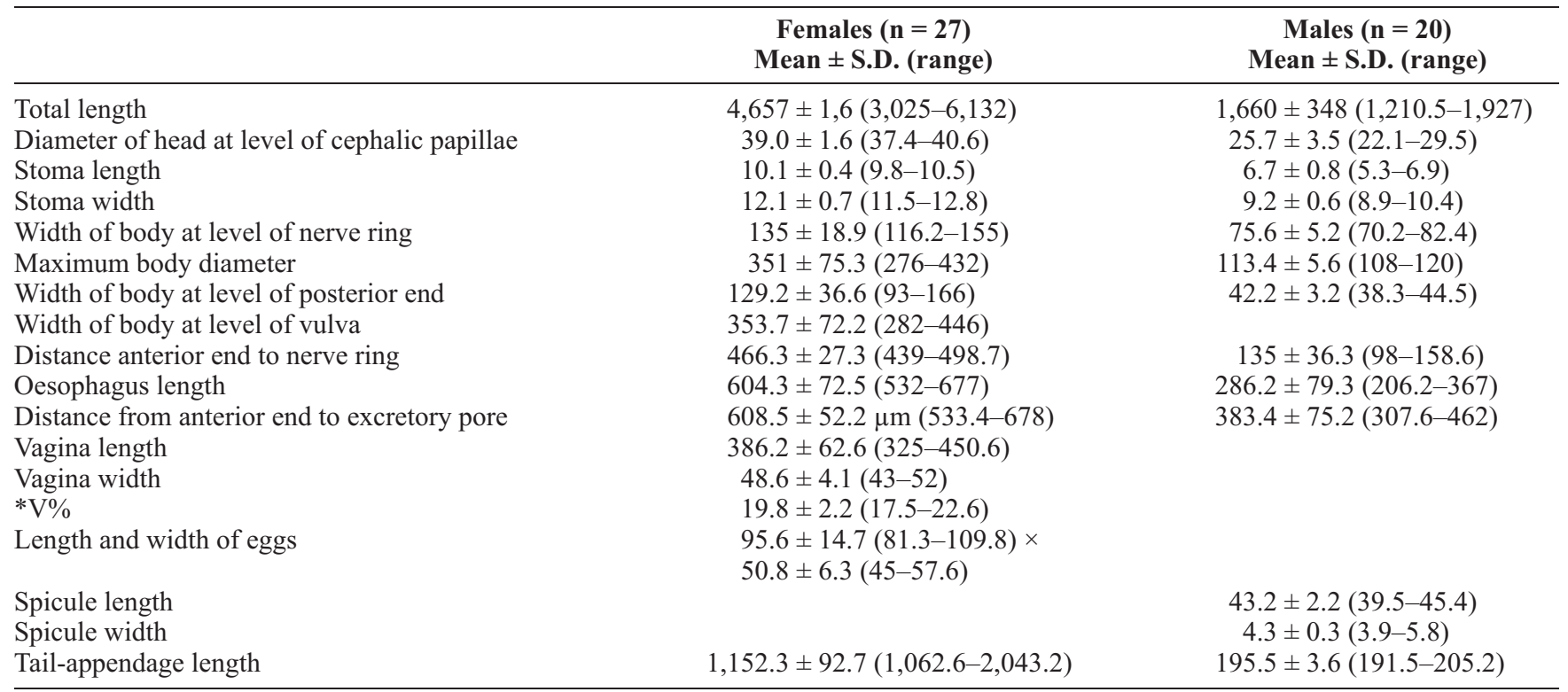

$* V$ : (distance from anterior end to vulva/body length $) \times 100$.

strong, the posterior part of the corpus forms the metacorpus valvate, and therefore, the anterior and posterior parts of the corpus are differentiated easily, isthmus cylindrical and thin surrounded by nerve ring, ending in a rounded basal bulb heavily muscled and valvate (Figs 1, 6, 9). Excretory pore is situated at the base of the oesophagus (Figs 1,6). The vulva is slightly protruding and lies in the anterior third of the body (Figs 1, 9). Vagina long and heavily muscled (Fig. 1). Didelphic, prodelphic. Eggs small and elongate, with smooth shell (Figs 1, 10). Tail appendage very long and thin, reaching one third of the length of the body (Figs 4, 9).
Male (Table II) has the anterior end pointed, with a thin cuticle, slightly visible or absent striation (Fig. 4). The lateral alae are absent. Mouth and stoma are similar in structure to that of the female. Amphids are very small. The oesophagus resembles the female, with metacorpus and basal bulb valvate, separated by an isthmus cylindrical with the nerve ring. Excretory pore is located at the base of the oesophagus. There is one spicule that is straight and strong, without gubernaculum (Figs $2,11)$. Genital papillae arranged in one pair of small preanal papillae, and two pairs of postanal papillae, the last one at the base of the tail appendage (Figs 5, 11). Posterior end of the
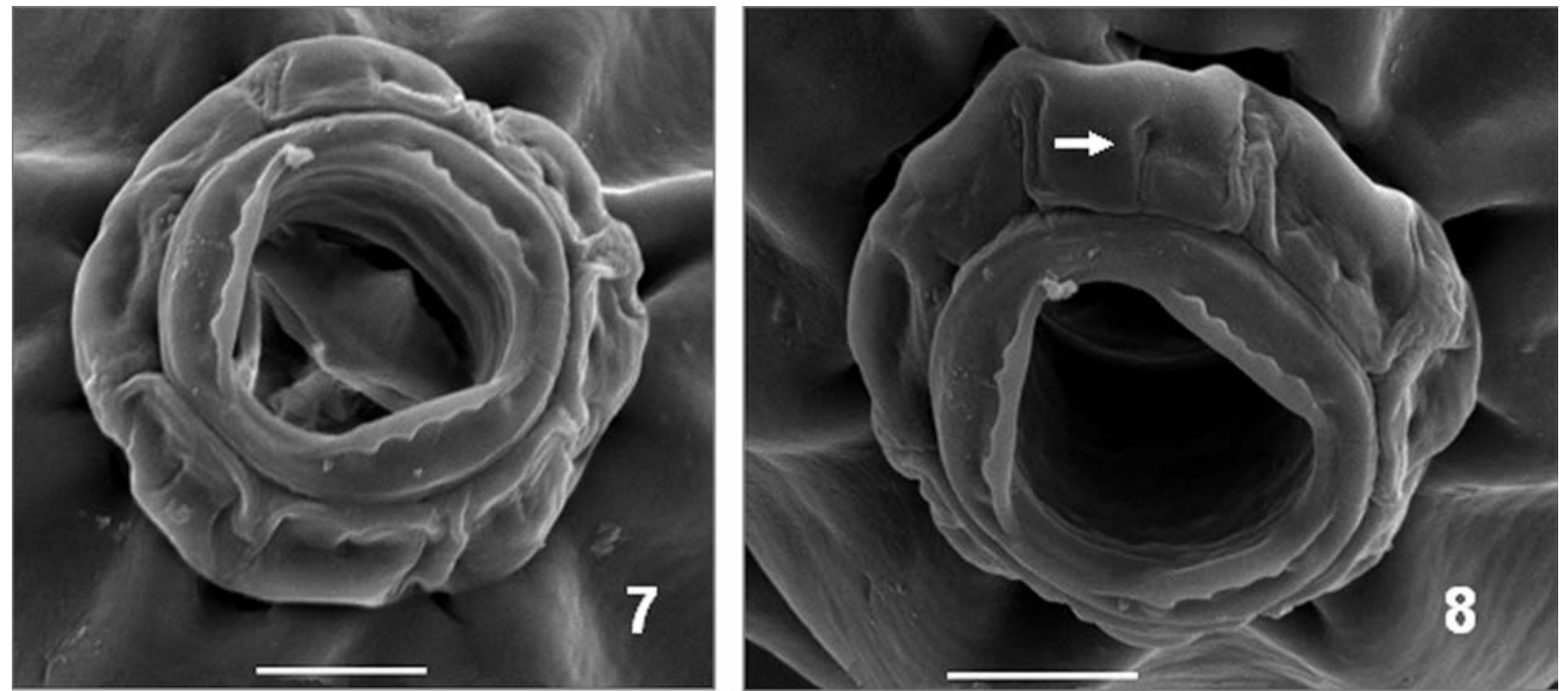

Figs 7-8. Scanning electron micrographs. Hammerschmidtiella eltalaensis sp. nov. 7. Anterior end of female showing three toothed lips, teeth in the buccal capsule. 8. Anterior end of female, pore of the amphid (arrow). Scale bars $=5 \mu \mathrm{m}$ 

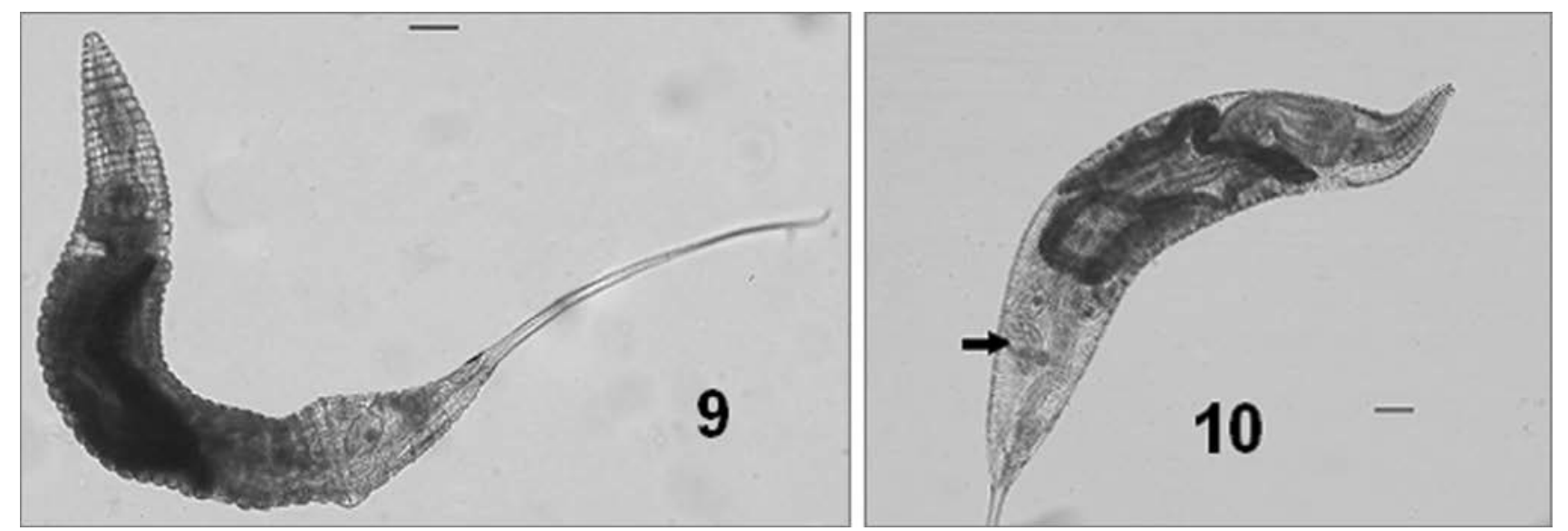

Figs 9-10. Light micrographs. Hammerschmidtiella eltalaensis sp. nov. 9-10. Females. Eggs (arrow). Scale bars $=100 \mu \mathrm{m}$

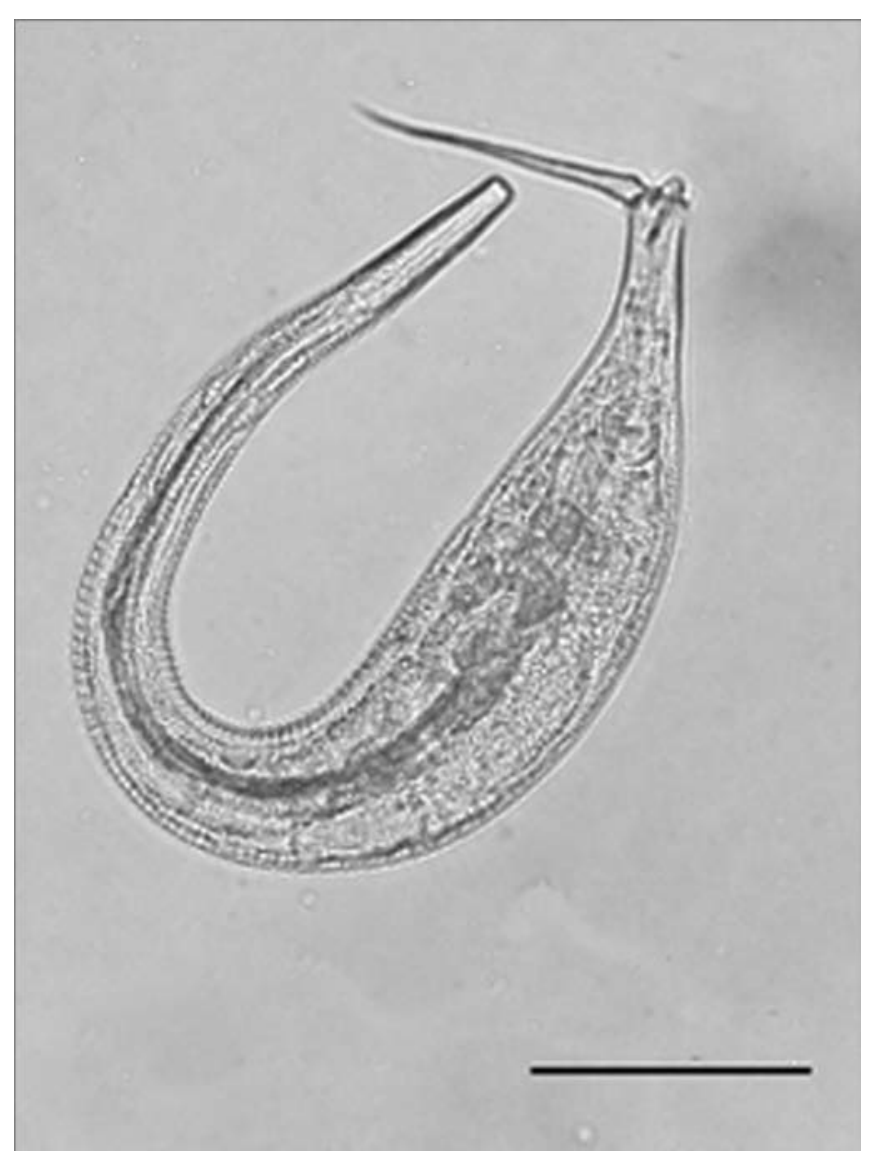

Fig. 11. Light micrograph. Hammerschmidtiella eltalaensis sp. nov. Male. Scale bars $=100 \mu \mathrm{m}$

body abruptly truncated posterior to anus with spine-like long tail appendage (Figs 2, 11).

\section{Discussion}

Our new species, Hammerschmidtiella eltalaensis exhibits some unique features: mouth with three toothed lips, buccal capsule short, wide with two mobile teeth on each side of mesostom, and the male genital papillae arranged in one pair of small preanal papillae, and two pairs of postanal papillae, in which the last one is at the base of the tail appendage. The set of all these characters justify its description as a new species. Hammerschmidtiella acreana Kloss, 1966, can be distinguished from our new species by having the metacarpus more developed than the basal bulb, the vulva is located near the middle of the body and the male is described only mentioning a series of caudal papillae (no mention of number), without preanal papillae. H. andersoni Adamson et Nasher, 1987 , is different by having the oral opening surrounded by six inner papillae and eight pairs digitiform labial papillae, the male has five pairs of caudal papillae, one pair subventral and one pair lateral preanal, one pair lateral adanal, one pair postanal and one pair at base of caudal appendage, and a small gubernaculum is present. H. basiri Singh et Kaur, 1988, is distinguished by the cuticle which is coarsely annulated along the body, mouth is guarded by eight submedian labiopapillae, the stoma with three tooth-like projections, the nerve ring is anterior to metacarpus, the excretory pore is at level of isthmus, the vulva position is anteriorly than our new species, and the male has one pair preanal papillae and a pair of postanal papillae. H. diesingi (Hammerschmidt, 1838), can be differentiated by the nerve ring situated anterior to metacorpus, the excretory pore at the base of the oesophagus, and in the male by one pair preanal papillae near the anus and a single unpaired ventral papilla near base of tail appendage. $H$. hochi Jex et al., 2005, is different mainly by having the pear shaped eggs, the nerve ring is posterior to metacorpus, the lateral alae are absent, and the tail is conoid and subulate. H. manohari Rao, 1958, is distinguished by the cuticle, striated throughout the length of the body, the nerve ring surrounding the metacorpus, and in the male by one pair of preanal, two pairs of adanal and an unpaired median postanal papillae; of the two pairs of adanal papillae, one pair lies close to the anus and the other pair, which is well developed, projects laterally from the tail appendage. H. neyrai Serrano Sánchez, 1945, is characterized by the absence of the lateral alae, the nerve ring is an- 
terior to metacarpus, the excretory pore is posterior to oesophagus, and the male with one pair preanal papillae, one pair postanal papillae and one single papilla at the base of the tail appendage. $H$. singhi Rao et Rao, 1965 is different by the nerve ring situated surrounding the corpus anterior located metacorpus, the caudal papillae comprised of two pairs of preanal, a pair of adanal and unpaired median postanal papillae situated immediately posterior to the anus at the base of the tail appendage.

For all these reasons we consider Hammerschmidtiella eltalaensis as a new species parasitizing cockroach from Argentina.

Acknowledgements. We would like to thank Mrs. Patricia Sarmiento from the Scanning Electron Microscopy Service (Museo de Ciencias Naturales, La Plata Argentina) for preparation of the material. Many thanks also to two anonymous reviewers for the constructive comments on the manuscript.

\section{References}

Adamson M.L., Nasher A.K. 1987. Hammerschmidtiella andersoni n. sp. (Thelastomatidae: Oxyurida) from the diplopod Archispirostreptus tumuliporus in Saudi Arabia with comments on the karyotype of Hammerschmidtiella diesingi. Proceeding of the Helminthological Society of Washington, 54, $220-224$.

Adamson M.L., van Waerebeke D. 1992. Revision of the Thelastomatoidea, Oxyurida of invertebrate hosts. I. Thelastomatidae. Systematic Parasitology, 21, 21-63.

Baumholtz M.A., Parish L.C., Witkowski J.A., Nutting W.B. 2008. The medical importance of cockroaches. International Journal of Dermatology, 36, 90-96. DOI: 10.1046/j.13654362.1997.00077.

Biswas P.K., Chakravarty G.K. 1963. The systematic studies of the zooparasitic nematodes. Zeitschrift für ParasitenKunde, 23, $411-428$

Brenner R.J., Koehler P., Patterson R.S. 1987. „Health Implications of Cockroach Infestations". Infestations in Medicine, 4, 349355.

Chitwood B.G. 1932. A synopsis of nematodes parasitic in insects of the family Blattidae. Zeitschrift für ParasitenKunde, 5, 14-50.

Eggleston P.A., Wood R.A., Rand C., Nixon W.J., Chen P.H., Lukk P. 1999. Removal of cockroach allergen from inner-city homes. Journal of Allergy and Clinical Immunology, 104, 842-846. DOI: 10.1016/S0091-6749(99)70296-4.

Farooqui M.N. 1966. Blattelicoloides blatti gen. et sp. nov. from Blatella germanica. Indian Journal of Helminthology, 18, 97100.

(Accepted October 12, 2011)
Gupta N.K., Kaur J. 1978. On some nematodes from invertebrates in northern India. Part I. Revista Ibérica de Parasitología, 38, $301-324$

Jarry D.T. 1964. Les Oxyurides de quelques Arthropodes dans midi de la France. Annales de Parasitologie Humaine et Comparée, 39, 381-508.

Jex A.R., Schneider M.A., Rose H.A., Cribb T.H. 2005. The Thelastomatoidea (Nematoda: Oxyurida) of two sympatric Panesthiinae (Insecta: Blattodea) from southeastern Queensland, Australia: taxonomy, species richness and host specificity. $\mathrm{Ne}-$ matology, 7, 543-575.

Kloss G.R. 1966. Revisão dos nematóides de Blattaria do Brasil. $P a-$ peis Avulsos do Departamento de Zoologia, Sao Paulo, 18 147-188.

Pessoa S.B., Correa C. 1926. Notas sobre os oxyurus parasitas das barata domestica com descripcao de una nova especie: Oxyurus australasiae n. sp. Memorias Instituto Butantan (Sao Pablo), $3,71-74$.

Rao P.N. 1958. Studies on the nematode parasites of insects and other arthropods. Arquivos do Museu Nacional, Rio de Janeiro, 46 , 33-84.

Rao P.N., Rao V.J. 1965. A description of a new species of the genus Hammerschmidtiella Chitwood, 1932 (Nematoda: Oxyuridae). Rivista di Parassitologia, 26, 9-12.

Shah M.M. 2007. Some studies on insect parasitic nematodes (Oxyurida, Thelastomatoidea, Thelastomatidae) from Manipur North-East India. Acta Parasitologica, 52, 346-362. DOI: 10.2478/s11686-007-0051-y.

Serrano Sánchez A. 1945. Hammerschmidtiella neyrai n. sp. en Periplaneta orientalis L. en Granada. Revista Ibérica de Parasitología, Tomo extraordinario, 213-215.

Singh H.S., Kaur H. 1988. On a new nematode, Hammerschmidtiella bisiri n. sp. from Periplaneta americana. Indian Journal of Parasitology, 12, 187-189.

Singh H.S., Agrawal A. 1998. Further observation on Hammerschmidtiella diesingi Chitwood, 1932, with a note on early embryonic development and validity of various species of the genus. U.P.J. Zoology India, 18, 27-36.

Spiridinov S.E. 1984. New oxyurid species from the intestine of Rhinocricus sp. Trudy Zoologicheskogo Instituta, 126, 33-49.

Sporik R., Squillace S.P., Ingram J.M., Rakes G., Honsinger R.W., Platts-Mills T.A. 1999. Mite, cat, and cockroach exposure, allergen sensitization, and asthma in children: a case-control study of three schools. Thorax, 54, 675-680.

Vythilingam I., Jeffery J., Oothuman P., Abdul Razak A.R., Sulaiman A. 1997. Cockroaches from urban human dwellings: isolation of bacterial pathogens and control. Southeast Asian Journal of Tropical Medicine and Public Health, 28, 218-222.

Zervos S. 1987. Protrellus dalei n. sp.. Blatticola barryi n. sp. and Suifunema mackenziei $\mathrm{n}$. sp. thelastomatid nematodes from New Zealand cockroaches. New Zealand Journal of Zoology, 14, 239-250. 